\title{
A CONSPECTUS OF SOLANACEAE TRIBE ANTHOCERCIDEAE
}

\author{
L. HAEGI \\ (Accepted for publication 13.2.1981)
}

\section{ABSTRACT}

Haegi, L. (National Herbarium of New South Wales, Royal Botanic Gardens, Sydney, Australia 2000) 1981. A conspectus of Solanaceae tribe Anthocercideae. Telopea 2 (2): 173-180.-A summary of the taxonomy of Anthocercis and related genera is presented. These genera all belong to tribe Anthocercideae which consists of seven genera of which two, Crenidium Haegi and Grammosolen Haegi, are newly described. Anthocercis Labill. and Anthotroche Endl. are redefined while Cyphanthera Miers is reinstated. The new name Symonanthus Haegi is provided to replace Isandra F. Muell. nom. illeg. for another genus to which 'Anthocercis' aromatica is transferred. Duboisia R. Br. remains unchanged. Two new species, Crenidium spinescens Haegi and Cyphanthera miersiana Haegi, and several infraspecific taxa are described. New combinations necessitated by the reclassification are provided, and a diagnostic key to the genera of tribe Anthocercideae is presented.

\section{INTRODUCTION}

The taxonomy of Anthocercis and related genera has received little attention since Bentham's (1868) treatment in 'Flora Australiensis'. Since that time a related new genus (Isandra) and several new species have been described and material unassignable to existing taxa has been collected. Past disagreement about generic delimitation (Miers 1853, Bentham 1868) has remained unresolved and the relationships of these genera to other genera in the family have remained unclear (D'Arcy 1979). An overview of this group of genera (Haegi 1979) and pollen-morphological investigations (Gentry 1979) provided support for its recognition as a distinct tribe [for which the earliest name is Anthocercideae (Don 1838, as 'Anthocerceae')] but a sound classification of the group was still lacking. For these reasons a comprehensive taxonomic revision of the group has been undertaken, and a summary of the taxonomy, together with nomenclatural changes, are presented here, in advance of the complete treatment, as a precursor to the imminent volume on Solanaceae for the new Flora of Australia. In addition to brief discussion of affinities and generic delimitation under each genus a diagnostic key to genera of the tribe is presented. The arrangement of the key reflects the generic relationships within the tribe.

\section{DIAGNOSTIC KEY TO GENERA IN TRIBE ANTHOCERCIDEAE G. Don}

1. Anthers bilocular; $n=36$; [fruit capsular]

2. Flowers bisexual; corolla with funnel-shaped tube and long \pm slender spreading lobes; stamens 4 , didynamous; anthers free; soft-wooded shrubs $[9 \mathrm{spp}$., in

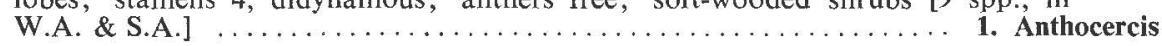

2.* Flowers unisexual (plants dioecious); corolla with $t$ cylindrical tube and short oblique lobes; stamens $3-5$, equal; anthers coherent in a cylinder at dehiscence; herbaceous plants with perennial rootstock [2 spp., in W.A.] ...... 2. Symonanthus

1.* Anthers unilocular; $n=28,30,31,35$ or 56

3. Fruit baccate; plants \pm glabrous; inflorescences many-flowered, $n=$ ? 28, 30 [3 spp., in all Aust. states except Tas., Vic., 1 species extending to New Caledonia]

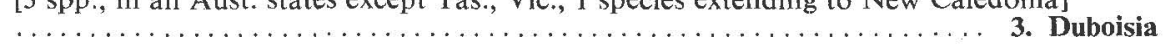

3.* Fruit capsular; plants pubescent (usually densely so) with dendritic eglandular hairs (simple or forked glandular hairs sometimes predominant); inflorescences few- to several-flowered

4. Stamens and style included or if exserted then not longer than the broadly funnel-shaped to patent corolla tube; corolla usually more than $10 \mathrm{~mm}$, always more than $5 \mathrm{~mm}$ in total length; corolla striations present; leaves present

5. Stamens 4, didynamous; anthers reniform, oblique at dehiscence; line of anther dehiscence terminal; $n=30$ [9 spp., in all states except N.T.]

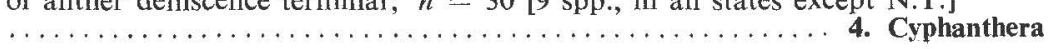


5.* Stamens 5, equal or unequal; anthers hippocrepiform, erect at dehiscence; line of anther dehiscence abaxial; $n=31$ or 56

6. Bracts present within inflorescence; corolla white with purple striations; corolla lobes glabrous on upper (inner) face, free and erect in bud; $n=56$ [2 spp., in S.A.] ............ 5. Grammosolen

6.* Bracts absent from inflorescence; corolla deep violet (though whiteflowered forms rarely occur); corolla lobes densely pubescent with dendritic hairs on upper (inner) face, coherent and with incurved apices in bud; $n=31$ [3 spp., in W.A.] ........... 6. Anthotroche

4.* Stamens and style exserted, much exceeding the narrow corolla tube in length; corolla $4 \mathrm{~mm}$ or less in total length; corolla striations absent; leaves absent except on very immature parts; $n=35$ [1 sp., in W.A.] ......... 7. Crenidium

\section{ANTHOCERCIS Labill.}

As treated here the genus Anthocercis is restricted to include only species with bilocular anthers and bisexual flowers, viz. A. viscosa R. Br., A. fasciculata F. Muell., A. angustifolia F. Muell., A. littorea Labill., A. ilicifolia Hook. (formerly included in $A$. littorea), $A$. intricata $\mathrm{F}$. Muell. (including $A$. arborea $\mathrm{F}$. Muell.), $A$. genistoides Miers (including $A$. spinescens F. Muell.), A. anisantha Endl. and A. gracilis Benth. Species with unilocular anthers referred to Anthocercis by Cunningham (1825), Mueller $(1855,1859)$, Bentham $(1846,1868)$ and all subsequent authors are assigned to the reinstated genus Cyphanthera Miers $(q . v$.$) . In essence this follows the concept$ of Miers (1853). The dioecious species originally described as $A$. aromatica by Gardner (1939) is transferred to Symonanthus (q.v.). Three new subspecies in Anthocercis are here described:

1. Anthocercis anisantha Endl. ssp. collina Haegi, ssp. nov. a ssp. anisantha ramis foliisque praecipue in partibus immaturis trichomatibus appressis antrorsis eglandulosis breviter tomentosis non trichomatibus longis porrectis glandulosis pubescentibus differt.

HoLotypus: A. E. Orchard 2171 , southwestern part of Yandinga Gorge $\left[32^{\circ} 33^{\prime} \mathrm{S}, 135^{\circ} 20^{\prime} \mathrm{E}\right.$, c. $50 \mathrm{~km}$ north of Minnipa, Gawler Ranges, South Australia, 15.8.1969 (AD). Isotypi: CANB, $\mathrm{K}, \mathrm{MO}$, PERTH distribuendi.

A. anisantha ssp. collina differs from ssp. anisantha in the branches and leaves (particularly on the immature parts) being closely tomentose mainly with antrorse, appressed eglandular hairs. In ssp. anisantha the indumentum is of long porrect glandular hairs. The new subspecies is confined to the Gawler Ranges and certain isolated hilltops of northern Eyre Peninsula, South Australia. The epithet, from the Latin collis, a hill, refers to the habitat of this taxon.

2. Anthocercis ilicifolia Hook. ssp. caldariola Haegi, ssp. nov. a ssp. ilicifolia calyce valde bulboso pariete crasso differt.

Holotypus: L. Haegi 1966 , c. $10 \mathrm{~km}$ by road SSW. of Kalbarri on coast track to Bluff Point, $27^{\circ} 41^{\prime} \mathrm{S}, 114^{\circ} 08^{\prime} \mathrm{E}$, Kalbarri National Park, Western Australia, 5.9.1979 (PERTH). Isotypi: CANB, K, NSW distribuendi.

A. ilicifolia ssp. caldariola is distinguished from ssp. ilicifolia by its thick-walled, markedly bulbous calyx. It is confined to the coastal area immediately about the township of Kalbarri, Western Australia, where ssp. ilicifolia does not occur. The epithet, from the Latin diminutive caldariola, a small cooking pot or cauldron, alludes to the bulbous calyx.

A. ilicifolia, published by Hooker (1830) is a name not in general use because the species to which it applies has been confused with and included under the very closely related species $A$. littorea. $A$. ilicifolia, which often occurs sympatrically with $A$. littorea, differs in its large pyramidal (not short racemose) inflorescence and the more brightly coloured flowers with larger tube and shorter, broader lobes. 
3. Anthocercis viscosa $R$. Br. ssp. caudata Haegi, ssp. nov. a ssp. viscosa lobis corollae (3.0-) 3.3-5.0 -plo [non 1.5-2.3 (-2.6) -plo] longioribus quam latioribus et tubo minimum (1.6-) 2.0 -plo (haud minus quam 1.5 -plo) longioribus differt.

Holotypus: L. Haegi 1225, upper southeast side of Condingup Peak, $33^{\circ} 46^{\prime} \mathrm{S}, 122^{\circ} 33^{\prime} \mathrm{E}$, c. $62 \mathrm{~km}$ castnortheast of Esperance, Western Australia, 6.10.1976 (PERTH). Isotypi: AD, CANB, K, L, MO, NSW distribuendi.

A. viscosa ssp. caudata which occurs on the southern coast of Western Australia between Esperance and Mt Ragged, and in the Walpole-Nornalup National Park, differs from ssp. viscosa in having corolla lobes (3.0-) 3.3-5.0 times longer than broad and usually at least twice, rarely only 1.6 times as long as the corolla tube. In ssp. viscosa which is found also in Western Australia, from Albany to Bremer Bay with one outlying occurrence near Denmark, the corolla lobes are only $1.5-2.3(-2.6)$ times longer than broad and less than 1.5 times as long as the corolla tube. The epithet, from the Latin caudatus, tail-like, refers to the narrow corolla lobes.

\section{SYMONANTHUS Haegi, nom. nov.}

RePlaced Synonym: Isandra F. Muell., [Syst. Census Austral. Pl.: 140 (1882), nom. nud.] S. Sci. Rec. 3: 2 (1883), nom. illeg., non Salisb., Gen. Pl. Fragm.: 67 (1866) [= Thysanotus R. Br. (Liliaceae)].

\section{Symonanthus bancroftii ( $F$. Muell.) Haegi, comb. nov.}

Basionym: Isandra bancroftii F. Muell., [Syst. Census Austral. Pl.: 140 (1882), nom. nud.] S. Sci. Rec. 3: 2 (1883).

\section{Symonanthus aromaticus (C.A. Gardner) Haegi, comb. nov.}

Basionym: Anthocercis aromatica C. A. Gardner, [Enum. Pl. Austral. Occ.: 116 (1931), nom. nud.] Hooker's Icon. Pl. ser. 5, 4: t. 3382 (1939).

Symonanthus is most closely related to Anthocercis with which it shares the characters of bilocular anthers, capsular fruit and gametic chromosome number of $n=36$ (Haegi, unpublished data).

At the time when $A$. aromatica was described the generic concepts of Anthocercis and 'Isandra' were such that these genera were separated on the basis of stamen number, the former with 4 and the latter with 5 stamens. Having 4 stamens only, the new species was placed in Anthocercis by Gardner who nevertheless recognised the many similarities of $A$. aromatica with 'Isandra' bancroftii. The transfer of Anthocercis aromatica to Symonanthus here is based on its possession in common with $S$. bancroftii of several characters which serve to distinguish Symonanthus from Anthocercis (see key above). Gardner stated that both species were andromonoecious. In fact, they are both dioecious, the flowers from male plants containing pollenbearing stamens but pistils lacking styles and ovules, and those from female plants containing fertile pistils but reduced stamens with anthers lacking pollen.

Symonanthus (from the Greek anthos, a flower) is named in honour of David Symon (Waite Agricultural Research Institute, Adelaide); his work in Australian botany has included significant contributions to our understanding of the biology and taxonomy of the Solanaceae.

\section{DUBOISIA $R$. Br.}

This genus consists of three species, D. myoporoides R. Br., D. leichhardtii (F. Muell.) F. Muell. and D. hopwoodii (F. Muell.) F. Muell. No nomenclatural changes are required. 


\section{CYPHANTHERA Miers}

Miers (1853) erected the genus Cyphanthera to accommodate those species with unilocular anthers previously assigned to Anthocercis. Later, Bentham (1868) reduced Cyphanthera to a section of Anthocercis sens. lat. and this has been followed by all subsequent authors. The inclusion of Cyphanthera in Anthocercis ignores the close affinity of the former with Duboisia, a genus which all authors have maintained as distinct. Both Cyphanthera and Duboisia have unilocular anthers and a gametic chromosome number of 30 (Barnard 1949; Haegi, unpublished data) [but see Ikenaga et al. (1979) for a report of $n=28$ in D. leichhardtii] while in Anthocercis the anthers are bilocular and the chromosome number is $n=36$. Cyphanthera differs from Duboisia in having capsular (not baccate) fruit and in a usually well-developed indumentum of dendritic hairs (not glabrous). For these reasons the three genera are maintained as distinct and Cyphanthera is here reinstated, necessitating the following new combinations. A new species and two new subspecies are also recognised and references to earlier combinations for accepted species provided.

\section{Cyphanthera anthocercidea (F. Muell.) Haegi, comb. nov.}

Basionym: Eadesia anthocercidea F. Muell, Trans. Philos. Inst. Victoria 2: 71 (1858).

This name applies to the Victorian material widely known as Anthocercis frondosa (Miers) J. M. Black. The type of the basionym of the latter name [Cyphanthera frondosa Miers], a specimen from Allan Cunningham's herbarium, is of unknown provenance, but is considered to be from a putative hybrid between Duboisia myoporoides and Cyphanthera albicans. Similar plants have been found from time to time at Douglas Park on the Nepean River, c. $50 \mathrm{~km}$ southwest of Sydney, the only known locality where the putative parents are sympatric. This was a locality probably visited by Cunningham. (1853).

2. Cyphanthera albicans (A. Cunn.) Miers, Ann. Mag. Nat. Hist. ser. 2, 11: 379

Basionym: Anthocercis albicans A. Cunn. in Field, Geogr. Mem. New South Wales: 335, t. $2(1825)$.

2a. Cyphanthera albicans ssp. tomentosa (Benth.) Haegi, comb. et stat. nov.

Basionym: Anthocercis albicans [var.] tomentosa Benth. in DC., Prodr. 10: 92 (1846), ‘ $\beta$. tomentosa'.

2b. Cyphanthera albicans ssp. notabilis Haegi, ssp. nov. a ssp. albicans corolla cremeo-alba tomento longiore $[0.3-0.5(-0.7) \mathrm{mm}]$, et a ssp. ovalifolia foliis longioribus [(15-) 18-25 mm] corolla majore [13-18 (-22) $\mathrm{mm}$ longa], differt.

Holotypus: L. Haegi 1379, Timor Rock, $31^{\circ} 16^{\prime} \mathrm{S}, 149^{\circ} 09^{\prime} \mathrm{E}$, Warrumbungle Ranges, New South Wales, 10.9.1977 (CANB). Isotypi: AD, K, L, MO, NSW distribuendi.

C. albicans ssp. notabilis and ssp. albicans both differ from ssp. tomentosa in the white to creamy-white (not yellow) corolla and in the longer tomentum [0.3-0.5 $(-0.8) \mathrm{mm}$ as compared with $0.2-0.25(-0.3) \mathrm{mm}]$ on the leaves and branches. Subspecies notabilis, which is restricted in occurrence to the Warrumbungle Ranges, where neither of the other subspecies is found, differs from ssp. albicans in its larger corolla [13-18 (-22) $\mathrm{mm}$ as compared with (6.5-) 8-11 (-13) $\mathrm{mm}$ long] and longer leaves [(15-) 18-25 $\mathrm{mm}$ as compared with 6-15 (-20) $\mathrm{mm}$ long]. C. albicans ssp. tomentosa is confined to western New South Wales while ssp. albicans occurs in the Great Dividing Range from northeastern Victoria through eastern New South Wales to far southeastern Queensland.

This subspecies takes its name from the Latin adjective notabilis, noteworthy, because of its relatively large attractive flowers and leaves. 

(1853).

3. Cyphanthera tasmanica Miers, Ann. Mag. Nat. Hist. ser. 2, 11: 377-378

Based Hereon: Anthocercis tasmanica (Miers) Hook. f., Fl. Tasmanica 1: 289, t. 92 [not $88 \mathrm{~A}$ as stated in text] (1857). (1853)

4. Cyphanthera scabrella (Benth.) Miers, Ann. Mag. Nat. Hist. ser. 2, 11: 380

Basionym: Anthocercis scabrella Benth. in DC., Prodr. 10: 192 (1846).

5. Cyphanthera racemosa (F. Muell.) Haegi, comb. nov.

Basionym: Anthocercis racemosa F. Muell., Fragm. 1: 211 (1859).

6. Cyphanthera myosotidea ( $F$. Muell.) Haegi, comb. nov.

Basionym: Anthocercis myosotidea F. Muell., Trans. Philos. Soc. Victoria 1: 20-21 (1855).

7. Cyphanthera miersiana Haegi, sp. nov. C. microphyllae et $C$. myosotideae affinis sed ab ambabus statura majore (c. $70 \mathrm{~cm}$ alta) foliis triangulari-cordatis ad basin subauriculata differt. Ab $C$. microphylla basibus staminum pubescentibus et absentia pilorum longorum in lobis corollae, et ab C. myosotidea foliis arcte appressis lobis corollae emarginatis praeterea differt.

Holotypus: C. A. Gardner 19061, $25 \mathrm{~km}$ east of Wiluna, Western Australia [c. $26^{\circ} 36^{\prime} \mathrm{S}$, $120^{\circ} 25^{\prime} \mathrm{E}$ ], 22.10.1966 (PERTH). Isotypi: AD, MO distribuendi.

C. miersiana is known only from the Wiluna area in Western Australia and is related to $C$. myosotidea and $C$. microphylla, with which it shares the characters of predominantly glandular indumentum, small leaves and short, broadly rounded corolla lobes. It differs from both in its greater stature (being about $70 \mathrm{~cm}$, not 25-40 cm tall) and in the triangular-cordate (not broadly ovate to oblong) leaves with subauriculate (not cuneate to truncate) bases. In $C$. microphylla the stamen bases are glabrous and the adaxial surface of the corolla lobes is pubescent, while in $C$. miersiana and $C$. myosotidea the stamen bases are pubescent and corolla lobes glabrous. Both $C$. microphylla and $C$. miersiana differ from $C$. myosotidea in having appressed, rather than oblique to spreading leaves, and emarginate, not entire corolla lobes.

C. miersiana is named in honour of John Miers, an English engineer who turned to botany and published extensively on the Solanaceae last century, contributing significantly to the knowledge of the endemic Australian genera.

8. Cyphanthera microphylla Miers, Ann. Mag. Nat. Hist. ser. 2, 11: 381 (1853).

Anthocercis microphylla F. Muell., Fragm. 1: $179(1859)$ is a taxonomic synonym of $C$. microphylla, being based on a different type.

9. Cyphanthera odgersii (F. Muell.) Haegi, comb. nov.

BASIONYM: Anthocercis odgersii F. Muell., Fragm. 10: 19 (1876). 
9a. Cyphanthera odgersii ssp. occidentalis Haegi, ssp. nov. a ssp. odgersii indumento longiore $1.0-6.0 \mathrm{~mm}$ (non $0.3-2.0 \mathrm{~mm}$ ) foliis majoribus [18-35 x 8-13 mm (non 11-20 x 7-11 mm)] et 2.3-3.8 -plo (non 1.1-2.0 -plo) longioribus quam latioribus, lobis corollae brevioribus [1.3-1.8 x $1.0-1.6 \mathrm{~mm}$ (non $2.0-2.5 \times 1.0-1.5 \mathrm{~mm}$ )] et trichomatibus glandulosis ad bases staminum carentibus differt.

Holotypus: L. Haegi 1100, Cowcowing Railway Siding, $31^{\circ} 00^{\prime} \mathrm{S}, 117^{\circ} 27^{\prime} \mathrm{E}$, Western Australia, 23.9.1976 (PERTH). Isotypi: AD, CANB, K, MO distribuendi.

The Latin adjective occidentalis, western, has been used in naming this subspecies, which occupies the western part of the distribution of $C$. odgersii.

The two subspecies of $C$. odgersii are distinguished as follows:

Leaves with length:breadth ratio of $1.1-2.0,11-20 \times 7-11 \mathrm{~mm}$; indumentum of branches $0.3-2.0 \mathrm{~mm}$ long; corolla lobes $2.0-2.5 \mathrm{~mm}$ long; stamen bases pubescent with eglandular and glandular hairs [Western Australia: Helms district of Eremaean Province, and Southwestern Interzone $\ldots \ldots \ldots \ldots \ldots \ldots \ldots \ldots \ldots$ ssp. odgersii

Leaves with length :breadth ratio of 2.3-3.8, 18-35 × 8-13 mm; indumentum of branches $1.0-6.0 \mathrm{~mm}$ long; corolla lobes $1.3-1.8 \mathrm{~mm}$ long; stamen bases pubescent with eglandular hairs only [Western Australia: Avon District of Southwestern province and Austin district of Eremaean Province] $\ldots \ldots \ldots \ldots \ldots \ldots \ldots \ldots$ ssp. occidentalis

\section{GRAMMOSOLEN Haegi, gen. nov.}

Frutices foliis perdurantibus alternis. Flores 1-2 in cymis bracteatis terminalibus vel axillaribus; cymae interdum $2-3$ simul ad idem nodum fasciculatae. Corolla regularis tubularis; limbus patens 5-lobatus; aestivatio loborum \pm induplicata marginibus loborum multum incurvis, margine uno saepe altrum lobi ejusdem imbricato, lobis liberis, erectis. Stamina ad basin corollae inserta inclusa 5 duobus longis et tribus brevibus; filamenta ad basin pubescentia; antherae hippocrepiformes erectae, linea dehiscentiae abaxiali. Ovarium ad basin disco annulari undulato circumcinctum. Fructus capsularis dehiscentia septifraga marginicida loculicidaque. Semina subreniformia; testa reticulata; embryo parum curvatus non circinatus. Numerus chromosomatum gametarum 56.

Holotypus: Grammosolen dixonii (F. Muell. \& R. Tate) Haegi (vide infra).

\section{Grammosolen dixonii ( $F$. Muell. \& R. Tate) Haegi, comb. nov.}

Basionym: Newcastelia dixonii F. Muell. \& R. Tate, Trans. \& Proc. Roy. Soc. South Australia 10: 81 (1888), 'Newcastlia Dixoni'.

\section{Grammosolen truncatus (Ising) Haegi, comb. nov.}

Basionym: Anthotroche truncata Ising, Trans. \& Proc. Roy. Soc. South Australia 46: 605, t. 38,39 fig. 1 (1922).

Grammosolen is most closely related to Cyphanthera and Anthotroche. From the former it is distinguished by its 5 fertile stamens and the hippocrepiform, erect [not oblique] anthers, and from the latter by the presence of bracts in the inflorescence, adaxially glabrous corolla lobes, white flowers and by the aestivation, the corolla lobes being free and erect [not coherent and incurved] in the bud. It differs from both in the gametic chromosome number of 56 (Haegi, unpublished data); this number is unique amongst those recorded in the Solanaceae. This genus, comprising two species, is endemic in South Australia. The name Grammosolen, from the Greek words gramme (stem gramm-), a line or stroke of a pen, and solen, a pipe, refers to the corolla tube which is white with purple striations.

Grammosolen dixonii was first described as a member of the Verbenaceae, in the genus Newcastelia (now correctly placed in the segregate family ChloanthaceaeMunir 1978) but clearly belongs to tribe Anthocercideae of the Solanaceae. 


\section{ANTHOTROCHE Endl.}

As treated here this genus includes three species, viz. A. myoporoides C. A. Gardner, A. pannosa Endl. (including $A$. blackii F. Muell. and A. healiana F. Muell.) and $A$. walcottii F. Muell. The species originally described as A. truncata is transferred to Grammosolen (q.v.).

\section{CRENIDIUM Haegi, gen. nov.}

Frutices praeter partes immaturissimas aphylli. Folia alterna caduca. Flores in fasciculis cymosis bracteatis ad nodos dispositi. Corolla regularis anguste tubularis; limbus patens, 5-lobatus; aestivatio loborum \pm induplicata lobis cohaerentibus et apicibusque incurvis. Stamina ad basin corollae inserta, multo exserta, reclinata, 4 didynama inter stamina longiora staminodio, vel stamine quinto interdum fertili; filamenta glabra; antherae \pm reniformes uniloculares. Ovarium ad basin disco annulari undulato circumcinctum. Fructus capsularis dehiscentia septifraga marginicida loculicidaque. Semina subreniformia; testa reticulata; embryo parum curvatus non circinatus. Numerus chromosomatum gametarum 35 .

HoLotypus et species singularis cognita: Crenidium spinescens Haegi (vide infra).

1. Crenidium spinescens Haegi, sp. nov. Frutex $1.0-1.7 \mathrm{~m}$ altus in statu maturo aphyllus. Rami spinescentes photosynthetici granulati, in partibus immaturis trichomatibus ramosis eglandulosis $0.03-0.05 \mathrm{~mm}$ longis dense breviter tomentosi. Folia in partibus immaturis remota obliqua ad adpressa sessilia caduca. Bracteae inflorescentiae $0.5-1 \times 0.3-0.5 \mathrm{~mm}$. Pedicellus calyxque extus dense tomentosi trichomatibus ramosis eglandulosis $0.1-0.2 \mathrm{~mm}$ longis. Corolla citrina, $2.5-4 \mathrm{~mm}$ longa, extus trichomatibus ramosis eglandulosis $0.1-0.2 \mathrm{~mm}$ longis, intus praecipue in lobis trichomatibus ramosis eglandulosis $0.1-0.25 \mathrm{~mm}$ longis cellulis late ellipticis instructa; tubus cylindricus ad obconoideus; lobi ovati, interdum late ovati. Stamina 3.5-4 et 4-5 mm longa, quintum ubi fertile $2.5-3.5 \mathrm{~mm}$. Ovarium 8-20 ovula capiens. Capsula ovoidea 4-4.5 x 2-2.5 $\mathrm{mm}$; semina 2-4, 2.5-4 x $1 \mathrm{~mm}$. Numerus chromosomatum gametarum 35 .

Holotypus: C. A. Gardner 13070, Mongers Lake [ = Lake Monger, c. $28^{\circ} 56^{\prime} \mathrm{S}, 117^{\circ} 19^{\prime} \mathrm{E}$ ], Western Australia, 12.6.1961 (PERTH). Isotypi: CANB, K, MO distribuendi.

The unilocular anthers of Crenidium indicate that it is related to the genera Duboisia, Cyphanthera, Grammosolen and Anthotroche. It differs from all of these in its very small flowers with stamens and style much exserted from the narrow corolla tube, which lacks striations, and in the stamen number varying from 4 to 5 . In Duboisia, Cyphanthera, Grammosolen and one species of Anthotroche (A. myoporoides) the stamens and style are included within the funnel-shaped corolla tube while in the remaining species of Anthotroche the stamens do not exceed the tube in length but are effectively exserted as a result of the upper half of the tube becoming patent at anthesis. The corolla tube is striated and the stamen number is constantly 4 or constantly 5 in all these genera. The gametic chromosome number of 35 (Haegi, unpublished data) is unique among those reported not only from tribe Anthocercideae but also from family Solanaceae as a whole.

The generic name Crenidium from the Greek krenidion, a small spring or fountain, alludes to the exserted stamens and style, and the Latin specific epithet refers to the spinescent branches characteristic of $C$. spinescens.

C. spinescens is endemic in southern eremaean Western Australia where it occurs on the margins of salt lakes in the Austin District of the Eremaean Province, the Coolgardie District (Southwestern Interzone) and the Avon District of the Southwestern Province. 


\section{ACKNOWLEDGEMENTS}

I wish to thank my colleagues at the National Herbarium of New South Wales, especially Jim Armstrong, Don McGillivray and Peter Wilson, for helpful discussions. I am indebted to David Symon and Bryan Barlow for guidance and encouragement and to the directors or curators of the following herbaria, and Mr A. C. Beauglehole, for provision of facilities and/or loan of specimens: AD, BRI, CANB, CBG, HO, MEL, NE, NT, PERTH, PERTHU, SYD. The support of the Australian Biological Resources Study in providing grants, initially at the Waite Agricultural Research Institute where this project was begun, and later at the National Herbarium of New South Wales, is gratefully acknowledged. I also thank the Western Australian National Parks Authority for co-operation in providing a collecting permit.

\section{REFERENCES}

Barnard, C. (1949). Microsporogenesis, macrosporogenesis and development of the macrogametophyte and seeds of Duboisia leichhardtii F.v.M. and D. myoporoides R. Br. Austral. J. Sci. Res. ser. b, 2: 241-248.

Bentham, G. (1846). Scrophulariaceae. In A. P. De Candolle (ed.), 'Prodromus Systematis Naturalis Regni Vegetabilis.' (Truettel \& Wurtz: Paris.) Vol. 10, pp. 190-192.

Bentham, G. (1868). 'Flora Australiensis.' (Lovell Reeve: London.) Vol. 4, pp. $470-481$.

Cunningham, A. (1825). A specimen of the indigenous Botany. In B. Field (ed.), 'Geographical Memoirs on New South Wales.' (Murray: London.) Pp. 325365.

D'Arcy, W. G. (1979). Chapter 1. The classification of the Solanaceae. In J. G. Hawkes, R. N. Lester \& A. D. Skelding (eds.), 'The Biology and Taxonomy of the Solanaceae,' (Academic Press: London.) Pp. 1-47.

Don, G. (1838). 'A General History of Dichlamydeous Plants.' Vol. 4, pp. 397-488. (London.)

Gardner, C. A. (1939). Anthocercis aromatica. Hooker's Icon. Pl. 34: t. 3382.

Gentry, J. L. (1979). Chapter 25. Pollen morphology of the Salpiglossideae (Solanaceae). In J. G. Hawkes, R. N. Lester \& A. D. Skelding (eds), 'The Biology and Taxonomy of the Solanaceae.' (Academic Press: London.). Pp. 327-334, pl. 25.1-25.15.

Haegi, L. (1979). Chapter 5. Australian genera of the Solanaceae. In J. G. Hawkes, R. N. Lester \& A. D. Skelding (eds), 'The Biology and Taxonomy of the Solanaceae.' (Academic Press: London.) Pp. 121-124.

Hooker, W. J. (1830). Anthocercis viscosa. Glutinous Anthocercis. Bot. Mag. 57: text accompanying t. 2961.

Ikenaga, T., Abe, M., Itakura, A. \& Ohashi, H. (1979). Alkaloid contents in leaves of artificial interspecific $\mathrm{F}_{1}$ hybrids between Duboisia myoporoides and $D$. leichhardtii. Planta Medica 35: 51-55.

Miers, J. (1853). On the genera of the tribe Duboisieae. Ann. Mag. Nat. Hist. ser. $2,11: 368-381,435-442$.

Mueller, F. (1855). Definitions of rare or hitherto undescribed Australian Plants. Trans. Philos. Soc. Victoria 1: 5-24.

Mueller, F. (1859). 'Fragmenta Phytographiae Australiae' (Melbourne.) Vol. 1, pp. $179,211$.

Munir, A. A. (1978). Taxonomic revision of Chloanthaceae trib. Physopsideae. Brunonia 1(4): 407-692. 